\title{
Toxic behavior in organizations and organizational entropy: a 4th industrial revolution phenomenon?
}

\author{
David A. L. Coldwell ${ }^{1}$
}

Received: 6 August 2020 / Accepted: 22 April 2021 / Published online: 28 April 2021

(c) The Author(s), under exclusive licence to Springer Nature Switzerland AG 2021

\begin{abstract}
The increasing prevalence of toxic leadership in business organizations can be at least partly attributed to increasing pressures emanating from the 4th industrial revolution. Pressures on business leaders from increased competition, environmental awareness, commitment to social purpose, and speed and spread of data communications have been made possible by computerisation and automation which have reached increased dominion during the COVID-19 pandemic. These pressures have created enormous challenges for organizational sustainability and survival. Competition to maintain market prominence and profitability and an excellent environmental awareness reputation has induced some leaders to resort to toxic behavior which has spread to employees driven to achieve specific organizational goals. For example, the unbalanced pursuit by leaders of Volkswagen and Boeing to maintain profits and market leadership resulted in a toxic climate that led to illicit employee behavior and affected their mental health, and the extreme purpose orientation of leadership of the Boy Shop promoted unsustainable employee practices arising from the singular and fixated pursuit of a strategic goal. Digital technology also has eroded employee leisure activity and privacy to the extent that many are on duty 24/7. Employee burnout and mental illness have also been exacerbated by the COVID-19 pandemic through employee isolation and the increasing dependence on technology. The purpose of the paper is to present eclectic examples of toxic behavior and its effects on organizational sustainability. The commentary indicates HRM's role in identifying and remedying destructive effects of toxic leadership before they take root in a post-COVID-19 world.
\end{abstract}

David A. L. Coldwell

David.coldwell@wits.ac.za

1 School of Business Sciences, Faculty of Commerce Law and Management, University of the Witwatersrand, Johannesburg, South Africa 


\section{Introduction: the digital era}

The digital era introduced what might be called a 'creeping revolution'; welcomed at first with the manifest benefits it brought to humanity in electronic innovations but more recently reviled as the downside to its irrevocable sway became increasingly apparent. The digital era has brought forth enduring benefits in the form of computation facilities, information capacity, media and communication technologies that quite simply were beyond most people's imagination a few decades ago. However, these benefits, underlined by the COVID-19 pandemic, have become tempered by costs that have begun to emerge with increasing frequency in the form of unrelenting pressure on personal privacy, performance expectations and social contact.

\section{The problem: the unholy trinity of toxic leaders, toxic employees, and toxic organizations}

Business leaders have been driven in an era of open information and total transparency to meet the requirements of maintaining profitability of the organization while ensuring it maintains a social 'purpose'. Leaders have responded to this pressure in different ways. Some have immersed themselves in the need to be environmentally aware by taking up the mantle of social activism. This approach can be profitable but is fraught with the risks of maintaining a reputation consistent with its activism or becoming so immersed in activism that the maintenance of profitability becomes a secondary issue that sometimes leads to organizational entropy through its channeling wasted energy in the pursuance of goals that undermine the fragile balance between profitability and purpose. That balance has been severely disrupted by the COVID-19 pandemic by virtue of the fact that the profitability of companies across-the-board has slumped significantly and has brought home the simple truth that without profits the many pledges for zero carbon emissions and other green endeavors swiftly fall by the wayside.

However, let me briefly illustrate the phenomenon of toxic leadership as it has recently appeared in several companies. Before doing so toxic leadership, toxic employees and toxic organizations need to be defined. First of all, toxic leadership needs to be distinguished from destructive leadership. Destructive leadership is defined by Einersen et al. (2007) as behavior by a leader to undermine the organization's objectives and employee well-being. In other words, it is the deliberate action by a leader to destroy the organization. Toxic leadership, on the other hand, does not embrace 'destructive intent'. The toxic leader may hold the best intentions for the organization and its employees, but because of a strategic fixation on the accomplishment of either the profitability or the social purpose of the organization, create a toxic climate that threatens the organization's sustainability. Thus, while destructive leadership is intentional in its destructive motivation, toxic leadership generates destructiveness vicariously. Toxic employees are those 
who acquiesce to toxic leadership fixated drives for either profits or purpose, at any cost. In doing so, they are complicit in generating the toxic organizational climate and contribute to overall organizational toxicity. Energy wastages through the relentless pressure made possible by the digital revolution drive employees in their attempts to implement fixated profit or purpose strategies undermine sustainability and threaten ultimate organizational entropy (Coldwell 2019).

\section{Extant evidence: toxic leadership and its repercussions}

There are many recent instances of toxic leadership that have had serious repercussions on thee long-term viability and sustainability of the firms concerned. For example, the Volkswagen 'Dieselgate' scandal was largely driven by the toxic leadership of the company in their pursuance and maintenance of company profitability, above all else. This singular strategic fixation excluded the company's other major responsibility, namely its social responsibility and social purpose. In this instance, to maintain VW profitability in the face of stringent European and United States exhaust carbon emissions, lent heavily on its technicians to find a solution 'at all costs' to its diesel-powered vehicles current inability to meet minimum emission standards in a severely limited time frame (Coldwell 2019). When this proved impossible, technicians at VW deliberately tinkered with the carbon emission monitoring equipment so that its production vehicles were able to meet required minimum standards. Once the news emerged of the company's blatant attempt to cheat, the resulting damage to its reputation and financial security was severe and protracted. Although VW survived the 'Dieselgate' crisis, it cost the company in the region of 30 billion US dollars to resolve (Trefis Team 2018), and there is little doubt that the company suffers, to this day, from the effects of the toxic leadership that generated the recent crisis.

Perhaps an even more devastating example of toxic leadership is provided by the Boeing crisis. Once again, this was initiated by leadership fixated on maintaining Boeing's profitability, at any cost. As it transpired, the cost was high in counted human lives lost.

The recent catastrophic twin crashes of the 737 Max aircraft that killed all passengers and crew, amounting to of 348 lives lost, presents a further example where the leadership of an organization with a highly reputable history that became toxic through the pressurization of senior leadership generated by 'cut-throat' inter-firm competition (Coldwell 2019). Pressure from competition came from Airbus and the problem confronting Boeing was to produce an aeroplane $15 \%$ more fuel efficient than the current 737 models in time to successfully compete with Airbus. Boeing leadership was under intense pressure to find a solution to the competition from Airbus that threatened to undercut the company's profitability, and to do this in a very short time frame. Pressure on senior leadership was pushed downwards and rapidly filtered through to the engineers and computer personnel beset with the task 'to do whatever was necessary' to meet the target on time and keep Boeing competitive and profitable (Pontefract 2019). This injunction from Boeing's toxic leadership caused technicians to put together a stopgap and inherently unsafe aircraft. Rather 
than design a new aircraft from scratch, it was decided to extend the life and profitability of the highly successful 737 by installing two more powerful and economical engines which, because of their size, reduced the clearance of the engine cowlings from the ground. The aerodynamics of the original basic 737 design changed substantially because of this and created an additional hazard of stalling through a too acute 'angle of attack' after take-off. To counteract this danger, Boeing introduced a computerized anti-stall system that simply took over when it considered the line of attack likely to cause the aircraft to lose control and plummet to earth. In theory, the pilot is able to override the computer system and take control manually when considered necessary, but in the case of both 737 max crashes this was not possible, either because the pilots had not received sufficient training to use the new system (Boeing's view) or because the aircraft was fundamentally flawed in design (the view of Lion and Ethiopian Airlines). Unfortunately, however, the crises were compounded by Boeing's CEO who reacted tardily and unapologetically to the twin disasters. The Boeing toxic leadership pressure had also spread to the Federal Aviation Administration (FAA) whose job it is to license aircraft only when they meet strict safety standards and requirements. The FAA did in fact give its safety approval for the 737 max, but only after inordinate pressure from Boeing's leadership (Pontefract 2019).

On the other side of the coin, fixation by leaders on social responsibility, or "purpose' of the organization can also generate toxicity capable of destroying it.

Roddick's Body Shop (Roddick 1991) presents an example of leadership emphasis on social purpose rather than profits which led to it becoming a leader in the manufacturing and retailing of eco-friendly cosmetics. The company became enormously profitable. However, the fixation of the leadership on social purpose made it become progressively toxic which, ultimately, undermined its economic viability and long-term sustainability.

The Body Shop was founded on social activism and its leadership strongly pursued the principles of social and environmental change. Anita Roddick (1991) saw business as more than the unrelenting pursuit of profit, for her it existed primarily to influence social change and to make the world a better place to live in. Her focus, leadership drive and strategic purpose emphasized human rights and environmental preservation. The company recruited and selected employees who embraced these values in their business behavior. However, as time progressed, the leadership fixation on social purpose became increasingly toxic and promoted toxic employee behavior. The resulting toxic organizational climate was one where the drive and emphasis on people and community welfare engendered social activism in employees reached such a fevered pitch that it began to threaten the economic sustainability of the organization itself. Ultimately, and largely as a result of this toxic leadership fixation on organizational purpose embraced by its employees, the company became the object of a number of ethical controversies regarding its adoption of specific social activist causes and was sold to L'Oréal.

Although social activism and emphasis on social and environmental change were the main reasons for the Body Shop's initial success, the company lost sight of its responsibility to maintain economic sustainability and the leadership and employee extreme social activist wasted energy caused it to entropy. Today, it is owned by 
Brazilian Cosmetics Company "Natura Cosméticos" who bought the company from L'Oreal in 2017.

A further example of the unholy trinity of toxic leadership, toxic employees and toxic organization from "purpose" activism is provided by calamitous case of Community Products Inc, (CPI). Ben Cohen, the co-founder of Ben and Jerry, embarked on a partnership venture with CPI to produce a new ice cream after attending a concert promoting the protection of the Brazilian rainforest. The new product called, 'Rainforest crunch' was made with Brazilian nuts and cashews. Ben Cohen, as president of $\mathrm{CP}$, contracted the company to distribute $40 \%$ of its profits from the sale of the new product to rainforest preservation groups and other selected international environmental projects. A further $20 \%$ was tagged for ' $1 \%$ for Peace' and $10 \%$ would be shared among employees. However, the validity of CPI's social and environmental purpose and activism eventually came under public scrutiny and burst like a pricked balloon. It was revealed the original small cooperative nut farmers that the initiative aimed to benefit were unable to meet the increasing demand for their product and comply with US health standards. In addition, it was discovered that shipments of nuts to be used as ingredients for the ice cream arrived with broken shells, cigarette butts, rocks, and coliform bacteria from the cooperative small-scale farms. In addition, 95\% of the nuts for 'Rainforest crunch' were supplied by large corporate suppliers which included notorious anti-union agribusinesses. Only $5 \%$ of the nuts came from local co-operatives. Ben and Jerry were forced to reconsider their 'purpose' social responsibility orientation which proved to be a façade Rainforest Crunch was hastily discontinued and CPI went bankrupt.

\section{Remedial action: who, with whom, when, and over what time period?}

HRM and SHRM are critical in ensuring that leadership and organizational values in organizations are driven towards attaining objectives that balance profits with purpose to ensure its sustainability. In established organizations in particular, HRM is required to act as a management 'bloodhound' and 'watchdog' to counteract, as soon as they become evident, tendencies toward toxic leadership in senior leaders and employee behavior.

Ulrich (1998, p.2) describes the on-going function of HRM in the following way: "In most companies HR is sanctioned mainly to play policy police and regulatory watchdog. It handles the paperwork involved in hiring and firing manages bureaucratic aspects of benefits and administers compensation decisions made by others" Although writing more than 2 decades ago, not much has changed for many HR departments. However, the watchdog aspect of HR alluded to by Ulrich (1998) needs to be extended and revitalized to monitor excessive profits or purpose orientations in senior management and to root out toxic forms of behavior as soon as they emerge by cautioning and advising senior management on the precariousness of adopting extreme profits or purpose strategies through setting unyielding paths that waste employee energy on fixated extreme narrow goals. Narendian (2019) suggests how $\mathrm{HR}$ can be a positive force in in fostering improvements in corporate governance by 
'sniffing' out toxic forms of leadership and/or employee behavior before they take hold and spread among employees and undermine organizational sustainability.

Bratton and Gold (2017) maintain that Strategic HRM is considered to be a continuous activity that requires constant adjustments in three major interdependent factors:

The values of senior management and leadership.

The environment in which the organization functions, and

The material, financial and human resources available to the firm.

The constant adjustment in senior managers and leader' values and strategic orientations need to be closely monitored and evaluated by HR. This is (or should be) a key aspect of HR's organizational competency. HR needs to act as the organizational 'bloodhound' to detect early leadership orientation imbalances in profits or purpose strategic drives and their effects on employee work behavior and mental health, before they threaten the organization's survival. The operational means for performing this function would be taken up by senior HRM as members of the corporate board and communicated and discussed with senior management and the CEO in viva, or electronic meetings (depending on the long-term effects of COVID-9) as part of an on-going report agenda.

In the example, cases of the crises at Volkswagen and Boeing could both have been avoided had HR pre-emptively acted on the toxic leadership drive downwards towards employees that focused the pursuit of profits above all else. Early instances of shifts in leadership orientations from a balanced approach should have been identified and acted on during the monitoring and evaluation process and practical remedial steps taken to redress strategy accordingly. The same applies to the Body Shop and Ben and Jerry where an increasing fixation by leaders and employees on social activism should have been identified by HR and senior management cautioned in the monitoring and evaluation process of the company. In both cases, senior management and leaders could have been cautioned that radical imbalances in corporate values towards the singular pursuit of profit or purpose with the creation of an organizational climate reflecting this imbalance, threatened the firms' survival.

The identification of toxic leadership during or post-COVID-19 will clearly have a more electronic focus, which may make early identification more difficult and preventative action by HRM more complicated. However, leaders use of video conferencing and electronic communications, and the symptoms of stress and mental health erosion among employees, observable in electronic communication and video body language, will enable HRM specialists to take the necessary pre-emptive steps to avoid them taking hold.

\section{Conclusion}

To conclude, what these examples described in this short paper have tried to show is that toxic leadership and employees driven to extreme profits or purpose organizational strategies by contextual business circumstances emanating from the 4 th 
industrial revolution will, sooner or later, put the organization on a unsustainable slippery inclined path which ends with entropy, unless HRM in particular and management in general takes prescriptive remedial steps briefly outlined above, before toxic leadership takes root.

\section{Declarations}

Conflict of interest The author declares no conflict of interest.

\section{References}

Bratton J, Gold J (2017) Human Resources Management, 6th edn. Red Globe Press

Coldwell DAL (2016) Entropic citizenship behaviour and sustainability in urban organizations: towards a theoretical model. Entropy 18(12):453

Coldwell DAL (2019) Negative influences of the $4^{\text {th }}$ industrial revolution on the workplace: Towards a theoretical model of entropic citizen behaviour in toxic organizations. Internat J Environ Res Pub Health 16(15):2670

Einersen S, Aasland MS, Skogland A (2007) Destructive leadership behavior: a definition and conceptual model. Leadersh Quart 18(3):207-221

Narendian R (2019) Role of HR in corporate governance: a watchdog or bloodhound? NHRD Netw J 12(4):344-350

Pontefract D (2019). 'Boeing's 737 Max crisis is a Leadership issue'. Available online: https://www. forbes.com/sites/danpontefract/2019/03/18/boeings-737-max-crisis-is-a-leadership-issue/\#12750 4c16a0a (Accessed on 14 Apr 2019).

Roddick A (1991) Body and soul: profits with principles, the amazing story of Anita Roddick \& The Body Shop. Crown

Trefis Team (2018) 'The domino effect of Volkswagen's emissions scandal'. Forbes. Available online: https://www.forbes.com/sites/greatspeculations/2015/09/28/the-domino-effect-of-volkswagensemissions-scandal (Accessed on 8 Nov 2018).

Urlich D (1998) A new mandate for human resources. Harvard Business Rev. Available online: https:// hrb.org (Accessed on 25 May 2020). 